\title{
PLPP1 wt Allele
}

National Cancer Institute

\section{Source}

National Cancer Institute. PLPP1 wt Allele. NCI Thesaurus. Code C49416.

Human PLPP1 wild-type allele is located in the vicinity of 5q11.2 and is approximately 111 $\mathrm{kb}$ in length. This allele, which encodes phospholipid phosphatase 1 protein, is involved in the dephosphorylation of exogenous bioactive glycerolipids and sphingolipids. 